\title{
Sidon against Beirut: Space, Control, and the Limits of Sectarianism within the Jewish Community of Modern Lebanon
}

\author{
Aline Schlaepfer (D) \\ Department of Social Sciences, University of Basel, Basel, Switzerland \\ Corresponding author. Email: aline.schlaepfer@unibas.ch
}

\begin{abstract}
When the State of Greater Lebanon was established in 1920, the Jewish Community Council of Beirut was officially recognized as the central administrative body within Lebanon, and although smaller communities such as Sidon and Tripoli also had their own councils they were consequently made subject to the authority of Beirut. In this context of political overhaul, I argue that some Jewish actors made use "from below" of political opportunities provided by sectarianism "from above" - or national sectarianism-to garner control over all Jewish political structures in Lebanon. But by examining in particular activities in and around the Israelite Community Council in Sidon (al-Majlis al-Milli al-Isra'ili bi-Sayda), I show how and why these attempts to practice new forms of sectarianism were met with resistance, despite connections that tied Lebanon's Jews together administratively in one community.
\end{abstract}

Keywords: Beirut; Jews; Lebanon; sectarianism; Sidon; space

Sectarianism as both a practice and a discourse is a recurring discussion among scholars of the modern Middle East. To start with, it is necessary to clarify what we mean by sectarian or sectarianism, as misunderstandings may eventually freeze the scholarly debate. In the Lebanese context, the word al-tâa'ifiyya, as Fanar Haddad argues, is generally used to refer to, and more often than not to condemn, the confessional political system characteristic of modern Lebanon. Specifically, historians have shown that the Lebanese representative and legal confessional system (al-niz̧ām al-țấifî̀), partly inherited from 19th-century Ottoman reforms and the creation of the mutasarrifiyya (the governorate of Mount Lebanon) and later confirmed by the French colonial mandate, does not legitimately or naturally reflect a supposed deeply rooted division based on sects within Lebanese society. ${ }^{1}$

In his seminal work Fi al-Dawla al-Ta'ifiyya (On the Sectarian State), the Lebanese Marxist Mahdi 'Amil argues that this sectarian system resulted from a relation of power maintained by modern colonial and political elites who defined and articulated divisions: "What if sectarianism . . . is not something, but rather a political relation defined by a specific historical form of the class struggle, conditioned by the Lebanese colonial structures?" "Amil emphasized that because contingencies of sectarianism(s) are constantly reproduced, it is necessary to examine, not the sectarian phenomenon as an immemorial and fixed reality, but rather the context for its emergence. In line with this idea, Max Weiss proposes to

\footnotetext{
${ }^{1}$ Fanar Haddad, "Sectarianism and Its Discontents in the Study of the Middle East," Middle East Journal 71, no. 3 (2017): 363-82.

${ }^{2}$ Mahdi 'Amil, Fi al-Dawla al-Ta'ifiyya (Beirut: Dar al-Farabi, [1986] 2019), 20. The translation is mine. For close readings of 'Amil's intellectual project and recent translation of his work in English, see Samer Frangie, "Theorizing from the Periphery: The Intellectual Project of Mahdi 'Amil," International Journal of Middle East Studies 44, no. 2 (2012): 465-82; Hicham Safieddine, "Mahdi Amel: On Colonialism, Sectarianism and Hegemony," Middle East Critique 30, no. 1 (2021): 41-56; and Mahdi Amel, Arab Marxism and National Liberation: Selected Writings of Mahdi Amel. Arab Marxism and National Liberation, ed. Hicham Safieddine and trans. Angela Giordani (Leiden: Brill, 2020).

() The Author(s), 2021. Published by Cambridge University Press. This is an Open Access article, distributed under the terms of the Creative Commons Attribution licence (http://creativecommons.org/licenses/by/4.0/), which permits unrestricted re-use, distribution, and reproduction in any medium, provided the original work is properly cited.
} 
distinguish between several expressions or layers of sectarianism. Based on the case of the Shici community in the country, he identifies in particular two types of sectarianizing processes. One coming "from above" pertains to the strategy of divide and rule, controlled by the colonial administration and Lebanese political elite in the shape of national sectarianism: namely a series of allegedly homogenous sectarian units, politically distinct from each other, but all called Lebanese. The other comes "from below"; members of these communities reclaim sectarianism on their own terms, such as with demands for sectarian rights and political autonomy. ${ }^{3}$ Major Lebanese sects and their relations to sectarianism have been examined through the critical lens of historians, but the Jewish community to this day remains understudied from the perspective of modern Lebanese history. In this article, I locate and discuss the dynamics of conflicts within the Jewish community in the aftermath of the creation of Greater Lebanon. I show how some Jewish actors made use from below of political opportunities provided by sectarianization from above to attempt to garner control over new Jewish political institutions in Lebanon. But by examining in particular activities in and around the Israelite Community Council in Sidon (CCS; al-Majlis al-Milli al-Isra'ili bi-Sayda), I show how and why these attempts to practice sectarianism were met with resistance.

To understand why some in the Jewish community expressed resistance to sectarianism, it is important to look at another critique of the sectarian paradigm developed by scholars of modern Lebanon. When the sectarian eye is applied too systematically to all kinds of historical phenomena, these scholars argue, other expressions of tensions or solidarities can be neglected. The category of sectarianism can be useful, insists Ussama Makdisi, but it is only one among many other ways to understand how individuals articulate sameness and otherness, differences and similarities. After all, belonging to one of the eighteen formally acknowledged religious groups in Lebanon does not account for all conflicts in the history of the country. "Are sect and sectarianism meaningful analytical categories for the study of Lebanon?" asks Max Weiss. Differentiation is a subjective and multilayered process, Suad Joseph answers, and dynamics within Lebanese society should not be reduced to sect-specific mobilizations. ${ }^{5}$ It is therefore necessary to explore other categories of analysis in which state and society construct differences and similarities, such as class or sex or, for the purpose of this article, one's relation to space. ${ }^{6}$

In The Production of Space, French philosopher Henri Lefebvre examines how social relations, everyday practices, and territorial divisions conceived politically produce space. ${ }^{7}$ Conception and perception of space can in turn affect the ways in which individuals living in the same space imagine and construct sameness, as well as how they articulate otherness with people living elsewhere, even when they belong to the same political, social, or religious group. In Lebanon, in addition to political divisions based on sects, authorities also produce and control spatial norms likely to affect social life in the country, such as territorial divisions into governorates (muhäfaza), districts ( $q a \bar{d} \bar{a})$, and municipalities (baladiyya). Also, narratives of tensions and solidarities in relation to regions, such as north versus south, city life versus country life, mountain against the sea, or one city versus another-like Sidon and Beirut in the case I address-show that identities in relation to space potentially emerge in various contexts and

\footnotetext{
${ }^{3}$ Max Weiss, In the Shadow of Sectarianism: Law, Shi'ism, and the Making of Modern Lebanon (Cambridge, MA: Harvard University Press, 2010).

${ }^{4}$ Ussama Makdisi, "Pensée 4: "Moving Beyond Orientalist Fantasy, Sectarian Polemic, and Nationalist Denial," International Journal of Middle East Studies 40, no. 4 (2008): 559-60. See also Ussama Makdisi, Culture of Sectarianism: Community, History, and Violence in Nineteenth-Century Ottoman Lebanon (Berkeley, CA: University of California Press, 2000).

${ }^{5}$ I follow Fanar Haddad's suggestion to use words like sect-specific, sect-based, or sect-centric rather than sectarian. According to Haddad, sectarian refers to various expressions of enmity of others, and is therefore ambiguous, whereas sect- more clearly refers to the official religion (al-țầifa). Haddad, "Sectarianism," 364.

${ }^{6}$ Suad Joseph "Pensée 2: Sectarianism as Imagined Sociological Concept and as Imagined Social Formation," International Journal of Middle East Studies 40, no. 4 (2008): 553; Weiss, Shadow of Sectarianism, 5; Maya Mikdashi, "Sex and Sectarianism: The Legal Architecture of Lebanese Citizenship," Comparative Studies of South Asia, Africa, and the Middle East 34, no. 2 (2014): 279-93. Mikdashi addresses the notion of "sextarianism" to show how sectarian and sexual differences are intertwined politically.

${ }^{7}$ Henri Lefebvre, La production de l'espace (Paris: Anthropos, 1974), ch. 15. For the English translation, see The Production of Space, trans. Donald Nicholson-Smith (Malden: Blackwell, 2016).
} 
forms. ${ }^{8}$ In what follows, I contend that, despite connections that tied Lebanon's Jews together administratively in one community subsequent to the political restructuring of the country that took place in 1920, tensions and conflicts emerged between Sidon and Beirut, pertaining to their relations to space.

Although historical sources on the Jewish community in Sidon are still scarce, the Fonds Youssef Melhem Politi du Conseil Communal Israélite de Saïda archive uncovered in 2013 contributes to a better understanding of major political events and developments there from the 1920s to the 1960s. The archive is composed mainly of Arabic handwritten meeting minutes (MoM) for the Israelite Community Council of Sidon (CCS) between 1919 and 1959. It was digitized, partly translated into French by Yolla Polity (daughter of Youssef Politi, president of the CCS between 1931 and 1979), and made available to various archival institutions. I will examine the Fonds Politi along with other contemporary sources, such as Arab historiography on the city of Sidon, Jewish newspapers, as well as Western philanthropic reports. ${ }^{9}$

\section{Sidon, the South, and Interreligious Interactions}

Until the first half of the 19th century, the Ottoman eyalets of Sidon and Tripoli encompassed Syria's major port cities, including Sidon itself. ${ }^{10}$ However, a number of factors led to the economic, political, and administrative growth of Beirut at the expense of Sidon, and by the end of Egyptian rule over Syria (1831-40), Sidon's commercial preeminence had started to fade. As a result of these transformations of the geopolitical scene, the city increasingly lost its previous influence and prestige in the region. It progressively transformed into a provincial city subordinate to Beirut, which later became the administrative capital of the province bearing its name (Vilayet Bayrut). ${ }^{11}$ Although the rivalry between the two port cities of Beirut and Sidon never reached the level of that between Beirut and Damascus or Beirut and Tripoli, the capitalization of Beirut was received with bitterness among certain Saydawis. ${ }^{12}$ As Cyrus Schayegh has shown, witnesses from within tended to tackle the issue of Sidon's decline, as it was being "crushed" by Beirut, with nostalgia and despair. This bitterness is most visible in the case of the scholar Ahmad 'Arif al-Zayn, whose work I will examine below, and it persisted in later historiography on the city of Sidon, as James Reilly has shown. ${ }^{13}$ However, historical testimonies also focus on positive aspects. In a detailed study on the Ottoman province of Beirut published in 1917 by two Arab Ottoman officials, Muhammad Bahjat and Muhammad Rafiq al-Tamimi, entitled Wilayat Bayrut (Beirut Province), the authors-while depicting an overall negative impression of the city-also insist on Sidon's extreme beauty and the exceptional variety of plants, trees, flowers, and orchards. Strong and visible upper and middle classes existed among the various religious communities, and the recent establishment of new schools greatly contributed to the modernization of the city's structures. Generally, they found the

\footnotetext{
${ }^{8}$ Salim Tamari, Mountain against the Sea: Essays on Palestinian Society and Culture (Berkeley, CA: University of California Press, 2009).

${ }^{9}$ The archive was first preserved by Youssef Politi himself, in Sidon, then Beirut, and later in Tel-Aviv where he moved with his wife in 1973-74. After his death, the archive was transported to Paris, where it was uncovered in 2013 by his children. Digital copies of the archive should now be available at the Alliance Israélite Universelle archives in Paris, the Judaica Division from Harvard University, Bar Ilan University, and the Central Archives for the History of the Jewish People (CAHJP). It is available through the National Library of Israel (https://www.nli.org.il/he/archives/NNL_CAHJP004407367/NLI), where the original archive is located. Yolla Polity also is the author of "Les Juifs de Saïda (Sidon) à travers les archives du Conseil communal israélite (1919-1975)," Généalo-J 122 (2015): 24-31, where she relates the history of the archive, as well as the historical context of the Jewish community in Sidon.

${ }^{10}$ Eyalet was the name of the major provincial unit in the Ottoman administration, from the late 16th century until the Regulation for Provinces (Vilayet Nizamnamesi) was promulgated in the 1860s. Selçuk Akşin Somel, Historical Dictionary of the Ottoman Empire (Lanham, Md.: Scarecrow Press, 2003), 88, 320.

${ }^{11}$ Leila Tarazi Fawaz, Merchants and Migrants in Nineteenth-Century Beirut (Cambridge, MA: Harvard University Press, 1983), 22-27.

${ }^{12}$ Jens Hanssen, Fin de siècle Beirut (Oxford, UK: Oxford University Press, 2005), ch. 1. Hanssen uses the concept of "capitalization of Beirut" to refer to the process of conversion into a capital city, in a modern context of economic booming.

${ }^{13}$ Cyrus Schayegh, The Middle East and the Making of the Modern World (Cambridge, MA: Harvard University Press, 2017), 49-53. The quotation is from Fawaz, Merchants and Migrants, 26. For an in-depth analysis of the historiography produced by Arab historians on Ottoman Sidon, see James A. Reilly, The Ottoman Cities of Lebanon: Historical Legacy and Identity in the Modern Middle East (London: I. B. Tauris, 2016), 43-69.
} 
people from Sidon to be hard workers; "there is no trace of laziness in Sidon," the authors conclude. ${ }^{14}$ The report also emphasizes interreligious proximities in Sidon. When they discuss Sidon's social customs (al-'ädat al-ijtimáa'iyya) Bahjat and al-Tamimi insist that members of various sects (they describe Sunni, Shi i, Christian, and Jewish customs) were not isolated blocks and therefore did not have perceptibly separate habits. The officials even conclude from their visit to Sidon that tensions within religious communities in Sidon were generally much higher than among them, something they found to be "confusing." 15

In fact, as part of the process that led to the formation of Greater Lebanon in 1920, the French mandate incorporated large parts of Jabal 'Amil into what came to be known as South Lebanon. And although the South emerged in French administrative language as a predominantly Shici region, historical studies have successfully debunked deep stigma around a supposed monolithic community. Scholars have shed particular light on the heterogeneous nature of its society from the perspective of class and sect, and on the importance of interreligious interactions in its various urban centers. ${ }^{16}$ For instance, Toufoul Abou-Hodeib has examined the shared tradition of visiting shrines in various sites of Palestine and South Lebanon. She has shown how the repetitive nature of the ritual around the holy site of Maqam Sidun (literally "the abode of Sidon" in Arabic), or Nabi Saydun located south of Sidon where the prophet Zebulon, son of Jacob, is believed to be buried, and venerated by Muslims, Christians, and Jews alike contributed to shape the contours of a local interreligious urban identity around the city of Sidon. ${ }^{17}$

Abou-Hodeib's argument of religious plurality in South Lebanon echoes the work of the Shici scholar Ahmad 'Arif al-Zayn (1884-1960) on the city of Sidon. Because there was no historical research dedicated entirely to Sidon, al-Zayn decided to publish a compilation of articles he had originally published in al'Irfan (literally "knowledge"), a journal he himself founded in 1909, which became an important tool for the promotion of knowledge, culture, and education in the region, under the title Tarikh Sayda (The History of Sidon) in $1913 .^{18}$ In both Tarikh Sayda and al-'Irfan, al-Zayn addressed on numerous occasions the importance of interactions between religions and sects in Sidon, particularly in relation to religious celebrations. When Christmas falls very close to the Mawlid al-Nabi (Birth of the Prophet Muhammad), he noted that both celebrations were attended by Christians and Muslims alike. Also, when Christian Easter and Jewish Passover were celebrated on the same day in April 1922, the celebrations were interreligious. ${ }^{19}$

Following Lefebvre's notion of space production, shared practices, whether for interreligious or social purposes, could have in fact created special attachments to local spaces where these interactions had taken place and fostered local identity formation. With the concept of "ecumenical coexistence," Ussama Makdisi, although not directly addressing the spatial dimension per se, also argues that these attachments accounted for people living in them. Sidon, because of both territorial exclusion and strong interreligious

\footnotetext{
${ }^{14}$ Muhammad Bahjat and Muhammad Rafiq al-Tamimi, Wilayat Bayrut, vol. 1 (Beirut: Matba'at al-Iqbal, 1917 ), 165. European travelers and archaeologists who visited the region shared the Arab Ottoman officials' impressions of a "modern" and "prosperous" city. Ernest Renan, Mission de Phénicie (Paris: Imprimerie impériale, 1864) 362; Victor Guérin, Description géographique, historique et archéologique de la Palestine (Paris: Imprimerie impériale, [1868] 1880), 488.

${ }^{15}$ Bahjat and al-Tamimi, Wilayat Bayrut, 162-66; see also Sabrina Mervin, Un réformisme chiite. Ulémas et lettrés du Gabal 'Amil de la fin de l'Empire ottoman à l'indépendance du Liban (Paris: Karthala, 2000), 41.

${ }^{16}$ To name a few: Mervin, Un réformisme chiite; Tamara Chalabi, The Shi' is of Jabal 'Amil and the New Lebanon: Community and Nation-State, 1918-1943 (London: Palgrave Macmillan, 2006); Malek Abisaab, "Shiite Peasants and a New Nation in Colonial Lebanon: The Intifada of Bint Jubayl, 1936," Comparative Studies of South Asia, Africa and the Middle East 29, no. 3 (2009): 483-501; Weiss, Shadow of Sectarianism; Stefan Winter, The Shiites of Lebanon under Ottoman Rule, 15161788 (Cambridge, UK: Cambridge University Press, 2010); Lara Deeb, "Beyond Sectarianism: Intermarriage and Social Difference in Lebanon," International Journal of Middle East Studies 52, no. 2 (2020): 215-28.

${ }^{17}$ Toufoul Abou-Hodeib, "Sanctity across the Border: Pilgrimage Routes and State Control in Mandate Lebanon and Palestine," in The Routledge Handbook of the History of the Middle East Mandates, ed. Cyrus Schayegh and Andrew Arsan (London: Routledge, 2015), 395-407. For the various names of the holy site in Sidon, see Renan, Mission de Phénicie, 367; Guérin, Description géographique, 496; Ahmad 'Arif al-Zayn, Tarikh Sayda (Sidon, Lebanon: Matba'at al-Irfan, 1913 ), $106-7$.

${ }^{18} \mathrm{Al}$-Zayn, Tarikh Sayda, 3, 9. For an in-depth analysis of al-Zayn's life and the history of al-Irfan, see Silvia Naef, "La presse en tant que moteur du renouveau culturel et littéraire: la revue chiite libanaise al-Irfân," Études asiatiques, Revue de la société Suisse-Asie 50, no. 2 (1996): 385-97.

${ }^{19}$ Al-'Irfan 6, no. 1 (1920): 89-91; Ibid., 7, no. 8 (1922): 509.
} 
activities, perfectly illustrates the idea that a shared space can (although not always) "transcend sectarian difference." 20

\section{Jews in Modern Lebanon: Old and New Quarrels}

Before digging into the multilayered processes of differentiation within the Jewish community in Lebanon, historical context of its presence in modern Lebanon and Syria is necessary. ${ }^{21}$ The scholarly literature on the topic of Jewish circulations in the Mediterranean basin between Spain, Greece, Turkey, Palestine, Egypt, and the Maghrib shows that by the 19th century Ottoman cities of Syria had become major hosts for a wide range of Jewish populations. In addition to the preexisting Arabic-speaking Jewish populations, as well as earlier waves of Sephardi and Maghribi immigration, Ashkenazi Jews in great numbers settled in Syrian cities over the course of the century to escape anti-Semitic persecution in northern and eastern Europe. Hitler's later rise to power and the subsequent increase in German Jewish immigration became a major object of discussion in the Lebanese press. An announcement addressed to "Jews living abroad" (im Ausland lebende Juden) distributed in Beirut in 1939 by the German consulate to force Jews with German citizenship to take on additional names (Israel for men, Sara for women) to identify them, testifies to the significant presence of German Jews in the area. ${ }^{22}$ The Ashkenazi immigration sometimes left local Jewish institutions in a state of crisis. School officials wrote urging requests for funding from abroad to help support newly arrived pupils. ${ }^{23}$

After the creation of the State of Greater Lebanon in 1920, Jewish communities from Syria and Iraq also sought refuge in Lebanon, in waves. The most important immigration to Lebanon resulted from the 1925 Syrian revolt, which produced the temporary displacement of several hundreds of Jewish families from Damascus to Beirut, and from the creation of the State of Israel in 1948, notoriously making Lebanon "the only Arab country in which the number of Jews increased after the first Arab-Israeli war." ${ }^{24}$ This wave of Jewish refugees created a new state of crisis for Jewish school institutions in Lebanon. The director of the Alliance Israélite Universelle (AIU) school for girls in Beirut wrote to the headquarters in Paris asking for help. She had transformed her office into a classroom to host new pupils but room had nevertheless become scarce, she complained. ${ }^{25}$ It is worth noting here that the Jewish community's modern history echoes in several ways the historical narrative of Lebanon as a pays de refuge (country of refuge) for various religious communities, such as Armenians, Palestinians, and Syrians. ${ }^{26}$

\footnotetext{
${ }^{20}$ Ussama Makdisi, Age of Coexistence: The Ecumenical Frame and the Making of the Modern Arab World (Oakland, CA: University of California Press, 2019), 3.

${ }^{21}$ Works on the history of the Jewish community in modern Lebanon include Kirsten Schulze, The Jews of Lebanon: Between Coexistence and Conflict (Portland, ME: Sussex Academic Press, 2001); Tomer Levi, The Jews of Beirut: The Rise of a Levantine Community, 1860s-1930s (New York: Peter Lang, 2012); Franck Salameh, Lebanon's Jewish Community: Fragments of Lives Arrested (Cham, Switzerland: Palgrave Macmillan, 2019); Nagi Zeïdan, Juifs du Liban. D'Abraham à nos jours, histoire d'une communauté disparue (Versailles, France: Va Press, 2020); and the Saudi-based newspaper Arab News also has published a resourceful file on Jewish Lebanese history at https://www.arabnews.com/JewsOfLebanon (accessed 14 October 2020). See also Youssef Mouawad, “Maronites et juifs jusqu'en 1920. Evénements et perceptions de l'autre," in Maronites dans l'histoire. De Rebus Maronitarum, ed. Youssef Mouawad (Beirut: L’Orient des livres, 2017), 193-227; and Valérie Assan, "Le statut juridique des Juifs algériens des marges de l'Empire français," in Minorités en Méditerranée au XIXe siècle, ed. Valérie Assan, Bernard Heyberger, and Jakob Vogel (Rennes, France: Presses universitaires de Rennes, 2019), 121-32.

${ }^{22}$ British National Archives, London, FO 371/23280/1842, "Notice to German Jews in Beirut," Beirut, 13 March 1939. For in-depth discussion on the coverage of German Jewish immigration in the Lebanese press, see Götz Nordbruch, Nazism in Syria and Lebanon: The Ambivalence of the German Option, 1933-1945 (New York: Routledge, 2009), 21-24.

${ }^{23}$ Archives of the Alliance Israélite Universelle, Paris, Fonds Moscou C10, box 5, Lettre de Sélim Harari demandant de l'aide à l'Alliance en faveur des Juifs allemands réfugiés à Beyrouth, Beirut, 19 February 1934. See also Guy Bracha, "'The Germans are Coming!' The Jewish Community of Beirut Facing the Question of Jewish Immigration from Germany," Leo Baeck Institute Year Book 61, no. 1 (2016): 41-54.

${ }^{24}$ Quotation from Schulze, Jews of Lebanon, 76.

${ }^{25}$ Les Cahiers de l'Alliance Israélite Universelle (Paix et Droit) 28-29 (Paris: 1948-49).

${ }^{26}$ Jihane Sfeir, "Le Liban, pays de refuge. Généalogie des réfugiés arméniens, palestiniens et syriens (1915-2015)," Relations internationales 4, no. 172 (2017): 39-50.
} 
The Jewish community was marked by strong ethnic, national, and linguistic diversity, which came with its lot of challenges. In The Jews of Beirut: The Rise of a Levantine Community, Tomer Levi discusses the difficulties pertaining to political representation within the Lebanese Jewish community in such a context. Article 2 of the community statutes of 1909 stipulated that "the numbers of members in the council will be twelve, six of whom are natives, and six who are not natives," directly addressing the tensions between Ottoman and local Jews and foreign nationals. Levi also sheds light on a detailed report by the director of the Beirut branch of the AIU school between 1905 and 1909, Yomtov Semach. The teacher deplores the existence of ethnolinguistic divisions between "Arab Jews, Sephardic Jews, and Russian Jews." ${ }^{27}$ The distinction between the three groups, albeit approximate, appears in various European, Hebrew, and Arabic language sources, although at times under different names. Arab Jews (al-Yahüd $\left.a l^{-} A r a b\right)$ is often synonymous with oriental Jews (sharqi in Arabic and mizrahi in Hebrew) and usually refers to the Arabic-speaking Jewish populations who settled in the region prior to Sephardis. ${ }^{28}$ The latter originally came from Spain and some (but not all) kept using the Ladino language. Some historical sources used "Russian Jews" to refer to all Ashkenazi Jews who fled the pogroms in the late 19th century, even though some came from Germany and elsewhere. An additional distinctive group worth mentioning here because it is often included in the Sephardi category comprises the Romaniote, or Greek-speaking, Jews. Many kept a Greek name but not the language, like the Politi family discussed below, who spoke Arabic. $^{29}$

In the ever-growing field of "Mizrahi studies," or studies on Middle Eastern Jewry, the phenomenon of modern identity formation has been at the center of scholarly attention. On the one hand, works based on rabbinical sources or from the perspective of Istanbul during the Tanzimat period have shown how modern Jewish identities were already shaped by the mid-19th-century millet administrations. On the other hand, from the perspective of intellectual history, studies based on printed material, often in Arabic, as well as European, colonial, and Zionist accounts, emphasized contributions of Jews in the Arab public sphere. ${ }^{30}$ By exploring the complex and multilayered mechanisms of identity formation in Jewish communities, all these works have successfully relocated their histories within the field of Middle Eastern studies. With some notable exceptions however, very few studies have examined the impact of shared spaces on identity formation. Studies by Orit Bashkin and Dena Attar on Jews in northern Iraq emphasize the gap between Jewish experiences in Baghdad and those in Kirkuk, Mosul, and other places in the north. Similarly, Emily Gottreich Benichou examines the impact of shared spaces in the city of Marrakesh, in

\footnotetext{
${ }^{27}$ Yomtov Semach, A travers les communautés Israélites d'Orient (Paris: Alliance Israélite Universelle, 1931) and Paix et droit 4 (Paris: 1931), https://www.nli.org.il/en/newspapers/ped/1931/04/01/01/?\&e=-------en-20--1--img-txIN\%7ctxTI------------1. See also Levi, Jews of Beirut, 80-101, 96.

${ }^{28}$ Although the discussion on Arab Jews is beyond the scope of this paper, recent contributions to the debate include: Moshe Behar and Zvi Ben-Dor, eds., Modern Middle Eastern Jewish Thought: Writings on Identity, Politics, and Culture, 1893-1958 (Waltham, MA: Brandeis University Press, 2013); Abigail Jacobson and Moshe Naor, Oriental Neighbors: Middle Eastern Jews and Arabs in Mandatory Palestine (Waltham, MA: Brandeis University Press, 2016), 6-9; and Lital Levy, "The Arab Jew Debates: Media, Culture, Politics, History," Journal of Levantine Studies 7, no. 1 (2017): 79-103.

${ }^{29}$ Polity, "Les Juifs de Saïda (Sidon)."

${ }^{30}$ This literature includes, for the Ottoman period, Benjamin Braude and Bernard Lewis, eds., Christians and Jews in the Ottoman Empire: The Functioning of a Plural Society (New York: Holmes and Meier, 1982); Bruce Masters, Christians and Jews in the Ottoman Arab World: The Roots of Sectarianism (Cambridge, UK: Cambridge University Press, 2001); Avigdor Levy, ed., Jews, Turks, Ottomans: A Shared History; Fifteenth through the Twentieth Century (Syracuse, NY: Syracuse University Press, 2002); Yaron Harel, "The Importance of the Archives of the Hakham Bashi in Istanbul for the History of Ottoman Jewry," in Frontiers of Ottoman Studies: State, Province and the West, vol. 1, ed. Colin Imber and Keiko Kiyotaki (London: I. B. Tauris, 2005), 251-64; Yaron Harel, Syrian Jewry in Transition: 1840-1880 (Oxford, UK: Littman Library of Jewish Civilization, 2010); Michelle Campos, Ottoman Brothers: Muslims, Christians, and Jews in Early Twentieth-Century Palestine (Stanford, CA: Stanford University Press, 2011); Zvi Zohar, Rabbinic Creativity in the Modern Middle East (New York: Bloomsbury, 2013); and Shlomo Deshen and Walter P. Zenner, eds., Jews among Muslims: Communities in the Precolonial Middle East (London: Palgrave Macmillan, 2016), 173-86. For the post-Ottoman period, see Laura Zittrain Eisenberg, My Enemy's Enemy: Lebanon in the Early Zionist Imagination, 1900-1948 (Detroit, MI: Wayne State University Press, 1994); Orit Bashkin, New Babylonians: A History of Jews in Modern Iraq (Stanford, CA: Stanford University Press, 2012); Liora Halperin, Babel in Zion: Jews, Nationalism, and Language Diversity in Palestine, 1920-1948 (New Haven, CT: Yale University Press, 2015); and Aline Schlaepfer, Les intellectuels juifs de Bagdad. Discours et allégeances (Leiden: Brill, 2016). For a similar perspective but on Persian sources, see also Lior Sternfeld, Between Iran and Zion: Jewish Histories of Twentieth-Century Iran (Stanford, CA: Stanford University Press, 2018).
} 
the history of Jewish-Muslim relations in Morocco. ${ }^{31}$ Identities in these cases were not only imagined and shaped by religious connections, these scholars show, but also by local spaces they shared with other religious communities. In Lebanon, although Tomer Levi does not directly address the impact of space in the shaping of modern identities within the Jewish community, he nevertheless insists that the ethno-national diversity within the Jewish community was not the sole source of tension. He notes that Jews throughout the country were divided over "other quarrels," namely tensions between communities located in different cities (mainly between Beirut, Sidon, and Tripoli), but without going into further details. ${ }^{32}$

To understand the nature of these "other quarrels" it is worth digging more deeply here into the transformation in the status of Jews in the late and post-Ottoman period. Jews of the Ottoman Empire officially became a millet over the course of the 19th century in ways similar to the Armenians and Greeks. In 1835, the chief rabbi (hahambaşı) was appointed by the government in Istanbul and officially became both head and representative of all Jewish communities throughout the empire, with local hahambaşı offices in provinces, districts, and cities. The General Regulations of the Rabbinate (Hahamhane Nizamnamesi), the organic law for the Jewish millet promulgated in 1865 , later confirmed the centralization of Ottoman Jewry characteristic of the Tanzimat era. ${ }^{33}$ But the new rabbinical institution centralized in Istanbul was met with strong resistance in various provinces of the empire, and more often than not local authorities continued to exist parallel to authority imposed from Istanbul. In some cases, like Damascus, a new leadership pattern emerged, where two chief rabbis ruled at the same time. One was in charge of dealing with Ottoman authorities, whereas the other held a religious position. ${ }^{34}$ With the creation of the State of Greater Lebanon in 1920, things changed once more for the Jews who found themselves in what became Lebanon. Given the confessional nature of the political system in the country, the transition from millet to citizen was admittedly far from being clear-cut juridically speaking, as with other sects. But in representative politics, major reconfigurations of authorities took place. Ottoman provinces and districts, as well as administrative structures that depended on them, no longer existed, and Jews in Lebanon, who numbered approximately 3,500 according to the census conducted in 1921, all became part of the Lebanese "Israelite sect" (al-tâ̄'ifa al-Isrä'ìliyya). ${ }^{35}$ The authorities also recognized the Israelite Community Council (al-Majlis al-Milli al-Isra'ili) of Beirut created in the aftermath of the Young Turk revolution in 1908 as the central body within Lebanon. Although smaller communities in Sidon and Tripoli also had their own councils, these were consequently made subject to the authority of Beirut. And in 1922, the chief rabbi of Beirut became the chief rabbi for all Lebanon. ${ }^{36}$ By doing this the authorities, while reusing an already existing system based on confessional representation, also contributed to shaping from above a new national sect, the "Israelite sect," that did not exist as such previously, with new hierarchies, new control networks, and new spaces. Although political sectarianism per se was not entirely new, the scope and limits of national sectarianism were. The situation transformed into an opportunity from below for some to practice new forms of sectarianism and benefit from it.

\section{The Jewish Community in Sidon: A Localized History}

In Tarikh Sayda, Ahmad 'Arif al-Zayn estimated the total Jewish population in Sidon to be 250 in 1850 , and 819 (for a total number of 13,184 individuals) in 1908. The two Ottoman officials and authors of Wilayat Bayrut, Bahjat and al-Tamimi, present similar numbers: in 1910, 888 Jews were living in the heart of Sidon. According to the Montefiore census, there were 150 Jewish families in Sidon in 1839

\footnotetext{
${ }^{31}$ Emily Benichou Gottreich, Mellah of Marrakesh: Jewish and Muslim Space in Morocco's Red City (Bloomington, IN: Indiana University Press, 2006); Orit Bashkin, "Jews in an Imperial Pocket: Northern Iraqi Jews and the British Mandate," in The Routledge Handbook of the History of the Middle East Mandates, ed. Cyrus Schayegh and Andrew Arsan (London: Routledge, 2015), 370-82; Dena Attar, "A View from the Mosul Margins: Refocusing the History of the Iraqi Jewish Community" (MA diss., University College London, 2019).

${ }^{32}$ Levi, Jews of Beirut, 103-4.

${ }^{33}$ Avigdor Levy and Aksel Erbahar, "Haham Başı" and "Hahamhane Nizamnamesi," Encyclopedia of Jews in the Islamic World, ed. Norman A. Stillman, Brill Online, 2014, https://brill.com/view/package/9789004176782.

${ }^{34}$ Harel, Syrian Jewry, 61-66.

${ }^{35}$ Augustin Bernard, "Les populations de la Syrie et de la Palestine d'après les derniers recensements," Annales de géographie 33, no. 181 (1924): 73-79. See also Schulze, Jews of Lebanon, 133.

${ }^{36}$ Levi, Jews of Beirut, 74-104.
} 
and 171 in 1866. Jewish children in Sidon attended one of two Talmud Torah or Jesuit or Protestant schools, until a branch of the Alliance Israélite Universelle opened in 1902 (accepting around 120 pupils the first year). It was later followed by Hebrew schools and kindergartens in 1920. Until 1855, Jews only had one synagogue, but a second one was erected in the early 1860s. Both buildings were located in the center of Sidon. The Jewish community also had financial charge of maintenance of the Maqam Sidun until at least the late 1950s, as evidence shows that Jews submitted requests for financial help in 1957, after an earthquake partially destroyed the site. ${ }^{37}$

An account published in one of the first issues of the Jewish Arabic newspaper based in Beirut, al-'Alam al-Isra'ili (The Israelite World), in September 1921 gives a better sense of how the Jewish community in Sidon was represented or represented itself. Because al-'Alam al-Isra'ili, founded and edited by the journalist Salim Elyahu Mann, had the ambition of becoming the main organ for Arabic-speaking Jewish communities in Syria and Lebanon and even reaching readership in Palestine and Iraq, efforts were undertaken to cover current affairs in Sidon, although at times unsatisfactorily. ${ }^{38}$ An anonymous author, presumably a member of the Jewish community in Sidon, wrote about the growing isolation of the city in the region. Despite the zeal of the age-old Jewish community members in Sidon who "are neither lazy nor bored," and despite their numerous activities in local industry and commerce, their prosperity was in decay, the author argues. First, because of the departure en masse to Brazil and North America, the Jewish community had been progressively decreasing in number. In fact, important waves of Jewish transatlantic immigration from Sidon were observed at least until the 1930s, to the point that the Jewish community in Sidon was reportedly composed of only "old people and children." 39 Some were encouraged to return after the French occupation, hoping that the acquisition of land would apply to them as it did for Jews in Palestine. But these hopes proved to be a great disappointment, he bitterly concludes: "Yes, some have returned from exile (al-mahjar) after the occupation but the law for the land. . . applied to the Zionists did not apply to the Jews in Sidon." Second, they could not rely on external financial support, the author complains. Compared to other Jewish communities in the region such as Palestine that benefited from the support of external charitable associations, Sidon's Jews felt abandoned. A feeling of in-betweenness and isolation can be read between the lines; Beirut and Palestinian coastal cities seem to have somehow stolen Sidon's thunder by excluding it from regional influence, in the eyes of the anonymous author. ${ }^{40}$

Post-Ottoman reshuffling of territorial entities affected the Jews in Sidon on several levels, some of which differed from effects on other sects in the region. Like other coastal populations around the cities of Tripoli and Beirut, Saydawi Jews had to cope with the redefinition of what it meant to be a national sect, as well as with the centralization of authorities in Beirut, as I have described. But they had to face an additional challenge, this time specific to their Jewishness, and pertaining to mobility to the south. Laura Zittrain Eisenberg and Guy Bracha have convincingly shown that prior to World War I the northern borders of Eretz Israel were not precisely defined in the imagination of early Zionists, which is why they initially explored various sites for future Jewish settlements in South Lebanon. Sidon's oil and soap factories, in particular, attracted the interest of Zionist entrepreneurs who established strong connections with Jews in Sidon. ${ }^{41}$ To be sure, connections between Palestinian Jews and the Yishuv and Lebanese citizens and institutions continued well after the establishment of Greater Lebanon, as Caroline Kahlenberg

\footnotetext{
${ }^{37}$ Al-Zayn, Tarikh Sayda, 154; Bahjat and al-Tamimi, Wilayat Bayrut, 156; "Fonds Youssef Melhem Politi du Conseil communal israélite de Saïda," Minutes of Meeting of the Israelite Community Council of Sidon (hereafter MoM) and correspondence, 11 July 1957; Montefiore Endowment, "Search the Montefiore Censuses," accessed 27 June 2019, http:// montefiorecensuses.org; Schulze, Jews of Lebanon, 28, 44.

${ }^{38}$ With regard to the journal's readership in Iraq, see Guy Bracha, “A Letter from Iraq: The Writing of Iraqi Correspondents in al-'Alam al-'Isra'ili and Isra'il," Middle Eastern Studies 52, no. 1 (2016): 103. See also Schlaepfer, Les intellectuels juifs de Bagdad, 69-87.

${ }^{39}$ Paix et droit 4 (Paris: 1931), https://www.nli.org.il/en/newspapers/ped/1931/04/01/01/?\&e=-------en-20--1--img-txIN\% 7ctxTI-----------1.

40“Ṣayda”, al-'Alam al-Isra'ili, 15 September 1921, https://www.nli.org.il/en/newspapers/alalam/1921/09/15/01/?\&e=-------en20--1--img-txIN\%7ctxTI------------1.

${ }^{41}$ Guy Bracha, "Al-'Alam al-Isra'ili. Mekomo be-'olam ha-itonut ha-yehudit ve-ha-'aravit ba-mizrah ha-tikhon 'al-reka' ha-temurot be-kehilot Suria ve-Levanon” (PhD diss., Bar Ilan University, 2012), 200-4; Eisenberg, My Enemy's Enemy, 39-46.
} 
has shown. ${ }^{42}$ As a matter of fact, the question of southern borders was far from being settled after the declaration of Greater Lebanon. ${ }^{43}$ However, free circulation was partly reduced after that, and, more importantly, hopes for fruitful investments in Sidon were suddenly dashed. Also, as connections between Jews in Palestine and in Lebanon were being reduced, they progressively became limited to Beirut, as this grievance from Sidon addressed to the editorial board of al-'Alam al-Isra'ili, testifies: "How nice it would be if you [Salim Efendi Elyahu] could take two hours maximum of your time on your way [from Beirut] to Palestine to study the affairs and situation of our little community [in Sidon]." ${ }^{44}$ In other words, centralization of Lebanese power in Beirut in the north and isolation from the Palestinian Yishuv in the south weakened the activities and influence of Saydawi Jews in the region, which became increasingly localized.

Two external reports also document the conditions of Saydawi Jews living at the turn of the century. One was produced by the director of the Beirut branch of the Alliance Israélite Universelle, Meir Angel, in 1902, and the other was written on behalf of the American Jewish Joint Distribution Committee (JDC) by Benzion 'Uzziel and Jack Mosseri in 1919. ${ }^{45}$ The French and American reports emphasized in very alarming terms the misery of Sidon's population as a result of the city's decline, and the symptomatic replacement of luxuriant gardens, as well as of lemon and orange orchards, by dirt and dust. "Sidon, once the queen of the seas, is today nothing more than a dark and sad town of 15,000 to 18,000 souls . . . a big village with no commerce and industry," stated Meir Angel from AIU. 'Uzziel and Mosseri estimated that "no ghetto in the world can be worse than that of Sidon." As Tomer Levi points out, reporting on systematic misery, vulnerability, and backwardness of oriental Jewish communities was in fact necessary to justify activities and interventions from charitable foundations.

But more importantly, the fact that 'Uzziel and Mosseri insist on the total absence of any preexisting Jewish political structure in Sidon is of particular significance here: "no community organization whatever exists in the place." 46 In fact, I contend that there was political incentive behind the authors' choice to emphasize the incapacity of Sidon's Jewish community to rule itself appropriately and sustainably. All authors, whether Benzion 'Uzziel and Jack Mosseri reporting for JDC or Meir Angel for AIU, had strong connections and interests in Beirut. Whereas Angel's connection as director of the AIU branch in Beirut is obvious, 'Uzziel's and Mosseri's instrumental role needs further explanation. A few days after their first visit to Sidon, which took place in the context of a tour of Syria in 1919, on 15 February, the Israelite Community Council in Sidon was elected in the presence of Jack Mosseri himself, as well as that of two delegates representing 'Uzziel, who were themselves members of the community council in Beirut (M. Barzel and M. Darwish). And although Benzion 'Uzziel, as chief rabbi of Jaffa, had no direct authority in Beirut, he expressed his support for and solidarity with Beirut's Jewish authorities on several occasions. ${ }^{47}$

\footnotetext{
${ }^{42}$ Caroline Kahlenberg, "The Star of David in a Cedar Tree: Jewish Students and Zionism at the American University of Beirut (1908-1948)," Middle Eastern Studies 55, no. 4 (2019): 570-89.

${ }^{43}$ Fawwaz Traboulsi, A History of Modern Lebanon (London: Pluto Press, 2012), 86-87.

44،Kafākum Ayyuhā al-Nās Taḍlīlan”, Al-'Alam al-Isra'ili, 24 October 1932, https://www.nli.org.il/en/newspapers/alalam/ 1932/10/24/01/?\&e=-------en-20--1--img-txIN\%7ctxTI--------------1.

${ }^{45}$ A graduate from the University of Cambridge, Jack Mosseri settled in Egypt where he led the Select Committee for the Relief of Jews in Palestine. Before Benzion 'Uzziel was elected Sephardi chief rabbi of Mandatory Palestine in 1939, he served as the chief rabbi of Jaffa. See Ruth Kimche and Zvi Zohar, "Mosseri, Jack" and "Uzziel, Ben-Zion Me'ir Hayy," Encyclopedia of Jews in the Islamic World, ed. Norman A. Stillman, Brill Online, 2014, https://brill.com/view/package/9789004176782. The Alliance Israélite Universelle was founded in Paris in 1860. The organization's mission was to provide help and education for Jews around the world, independently from the Consistoire Israélite de France (Israelite Central Consistory of France).

${ }^{46}$ Meir Angel, "Rapport sur la communauté juive de Sidon," Bulletin de l'Alliance israélite universelle 27 (1902): 91-99, https:// www.nli.org.il/en/newspapers/bul/1902/01/01/01/?\&e=-------en-20--1--img-txIN\%7ctxTI-------------1 91. For a shorter version of the report in English, see Norman A. Stillman, The Jews of Arab Lands in Modern Times (New York: Jewish Publication Society, 1991), 197-98; American Jewish Joint Distribution Committee, "Report on Jewish Communities in Damascus, Beirut and Sidon," 13 February 1919, 7-8, http://search.archives.jdc.org/multimedia/Documents/NY_AR1921/00023A/ NY_AR1921_00893.pdf\#search=.

${ }^{47}$ Zvi Zohar, Ve-Lo Yiddah Mimenu Niddah. Yahaso shel ha-Rav Ben Tsiyon 'Uzziel la-Giyur ba-Zeman ha-zeh ke-Mishtakef bi-Teshuvotav ha-Hilkhatiyot (Jerusalem: 2012), ch. 3. I am grateful to Zvi Zohar for pointing this out.
} 
The newly elected CCS was composed of five members: Ishaq Diwan (treasurer), Ibrahim Barzilay (secretary), Musa Braun, Yusuf Nigri, and Ibrahim Khayyat. Some of them, like Nigri and Khayyat, known to be the most famous treasurers (șarräf) working for Istanbul, were already active before the change of regime. ${ }^{48}$ Although this shows some form of continuity with previous political practices, major reconfigurations of power also took place. In particular, the committee in Sidon was intentionally elected without a president, "so that it may act under orders from Beirut." ${ }^{49}$ From then on, the CCS was supposed to act and take all decisions with the approbation of Beirut, which would as well represent its interests. The absence of a CCS president, which later became an object of contention, gave members of the community council in Beirut who were involved in the creation of the CCS opportunities to exert political as well as financial control over Sidon. In other words, they used political tools provided by national sectarianism, namely the supposed political homogeneity of the Lebanese Israelite sect centralized in Beirut, to subject the CCS to their authority. However, the way state and communal authorities imposed and practiced national sectarianism soon produced resistance and hostility among some in the Saydawi Jewish community, whose voices I will examine in the next two sections.

\section{Musa Braun and Ibrahim Ma'tuq Nigri: Sidon's Voices of Dissent}

Two prominent members of Sidon's Jewish community in particular, Musa Braun and Ibrahim Ma'tuq Nigri, embodied dissent against the capital authority in Beirut, from the point of view of representative politics and finance. Paradoxically, although the report submitted to the JDC by Jack Mosseri and Benzion 'Uzziel deplored the absence of a communal structure for Sidon, it also provided evidence for such a structure: "A Hotel keeper by the name of Braun calls himself Chief Rabbi and President of a Va'ad composed of so called representative heads of families." ${ }^{50}$ Soon enough, by claiming the title of chief rabbi in Sidon in opposition to the centralization of the Chief Rabbinate of the Lebanese Republic in Beirut, the widowed innkeeper of Galician origins Musa (Moshe) Braun became the CCS's bête noire. ${ }^{51}$

On 15 February 1919, Braun, who previously worked for the Singer Corporation, manufacturer of sewing machines, joined the CCS as one of its five founding members. He was consequently assigned a few tasks, such as listing the names of the poor to be sent to a charitable association in Rio de Janeiro. But things quickly started to turn sour. Members of the CCS soon complained about Braun missing meetings and not completing his tasks. One major object of contention was control over the stamp of the Lebanese chief rabbinate. The stamp gave authority to validate religious ceremonies and contracts in the name of the chief rabbinate, in exchange for money. Repeatedly between 1919 and the late 1940s, Musa Braun used the stamp without the council's consent, even after its members took the decision to replace it to avoid usurpations. As soon as April 1919, the CCS addressed a personal request to Musa Braun to return the stamps he was using, followed in 1920 by a warning, insisting that he had no permission to proclaim himself chief rabbi ( $h \bar{a} \bar{k} h \bar{a} m b \bar{a} s h \bar{\imath})$. According to the council's investigation, Braun was living with a girlfriend (săhiba) "contrary to religious rule" and could therefore not claim the title of rabbi, least of all chief rabbi. When in 1922 Sulayman (Shlomo) Tagger officially became chief rabbi of Lebanon, he published an official announcement that there was no other chief rabbi in the country. ${ }^{52}$ More than a decade later, in May 1933, as members of the CCS still complained that Braun was using the title of chief rabbi despite multiple warnings, regional authorities intervened. The governor of South Lebanon Kamil (Camille) Shidyaq sent a formal request using similar warnings addressed to Braun. ${ }^{53}$ Two important documents, one decree by the high commissioner on 7 January 1933, and one by As'ad 'Aql, the public prosecutor of South Lebanon, on 1 March 1933, also communicated that "there was only one Israelite community in the Republic of Lebanon and therefore one chief rabbi." At this point, Musa Braun reacted officially for

\footnotetext{
${ }^{48}$ Al-Zayn, Tarikh Sayda, 163, 170. "Fonds Youssef Melhem Politi," MoM, 15 February 1919.

${ }^{49}$ American Jewish Joint Distribution Committee, "Report on Jewish Communities," 8.

${ }^{50}$ Ibid., 7. Va'ad is a Hebrew term meaning committee or council.

${ }^{51}$ The CCS meeting minutes provide exceptionally detailed information about the life of Musa Braun throughout the years. For instance, the minutes of the council's meeting that took place on 11 February 1940 are thirteen pages long, all devoted to Musa Braun, although the minutes usually do not exceed one page; "Fonds Youssef Melhem Politi," MoM, 11 February 1940.

${ }^{52}$ Al-'Alam al-Isra'ili, 25 May 1925. I thank Guy Bracha for sharing this.

${ }^{53}$ Letter from Kamil (Camille) Shidyaq, governor of South Lebanon, 16 May 1933; "Fonds Youssef Melhem Politi," MoM, 11 February 1940.
} 
Figure 1. Musa Braun's business card as "Grand Rabbin." https://www.facebook.com/BeirutSynagogue/ photos/10155578004596025 (accessed June 4, 2021).

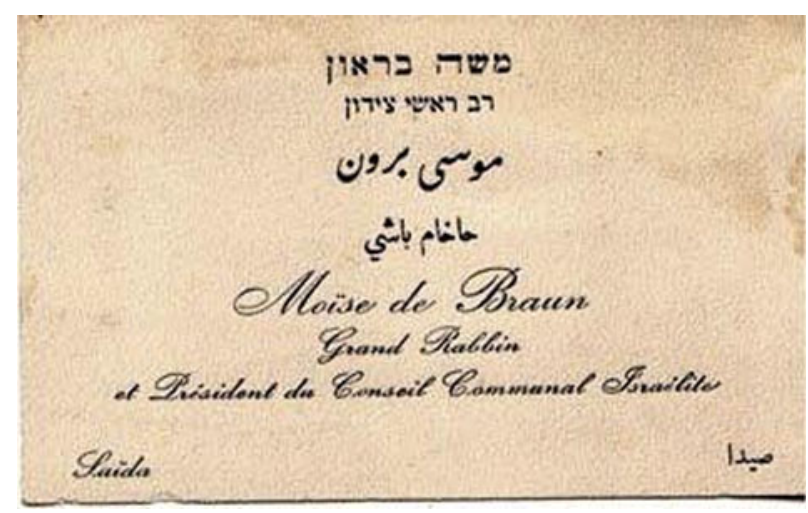

the first time, by answering that he had lost the stamp years ago. However, new evidence showed that he continued behaving as the legitimate chief rabbi of his community in Sidon (Fig. 1). On 1 April 1939, when Braun came to the synagogue dressed as a rabbi, wearing a turban (laffa) and a coat ( $j u b b a$ ), some Jewish attendees decided to stop praying as a sign of protest. But he celebrated the same year the wedding of a Jew from Sidon with a second wife from Tel-Aviv. ${ }^{54}$ In 1940, the CCS finally acted decisively to strip Musa Braun of his title and function (bi-'azlihi min wazífatihì) of chief rabbi. "The president would then inform the chief rabbi of the Lebanese Republic in Beirut which we consider to be bound to religiously, and to the communal council of Beirut administratively, of our decision."

By clinging to his title of chief rabbi, Musa Braun was arguably behaving according to former leadership practices in the city, when the rabbinical institution could be negotiated locally. Strong reactions from Beirut and the CCS against Braun's claims show that with the nationalization of the chief rabbinate for Lebanon in Beirut, this negotiation was technically no more possible. Despite the repeated threats and intimidation, however, Braun refused to acknowledge the legitimacy of the centralized religious authority in Beirut, and succeeded in maintaining his practice as the other chief rabbi in Sidon for many years, deliberately challenging and denying the authority of the chief rabbi of the Lebanese Republic based in Beirut. In fact, when he celebrated the wedding of a Cohen from Sidon with a Christian woman for the amount of 600 Lebanese pounds in 1947, he had been usurping the title for twenty-eight years, thus showing remarkable persistence in his opposition to Beirut. ${ }^{55}$

A similar contentious case involved the management of the awqāf (pious endowment, plural of waqf) revenues for the Jewish community. As was the case with other non-Muslim communities throughout the Ottoman Empire, Jews used the Muslim waqf institution, even though it was originally not their own, to regulate community revenues. ${ }^{56}$ According to the practice in Ottoman Sidon, a man named Yusuf Shmu'el Nigri was appointed in 1907 nāzir al-awqāf (administrator of the awqāf) by the religious Sunni court in Sidon (al-Mahkama al-Shar iyya al-Sunniya bi-Sayda). After the establishment of the State of Greater Lebanon and Jewish political reforms, Yusuf Shmu'el Nigri's position was maintained in Sidon, as from the perspective of the CCS the man had "been practicing for twenty years with the highest degree of honesty and accuracy," but this time under the supervision of the Israelite Community Council of Beirut. ${ }^{57}$ A commission of seven members was chosen, and control over all Jewish awqā $f$ became the responsibility of this commission alone, although in practice Yusuf Shmu'el Nigri was still referred to as the näzir al-awqäf.

One of his relatives, however, Ibrahim Ma'tuq Nigri, fiercely opposed the CCS's management of the awqäf revenues, for which he also claimed to be the legitimate administrator. Despite the official decision

\footnotetext{
${ }^{54}$ Letter from the chief rabbi in Beirut Bahbūt to CCS, 3 September 1939; "Fonds Youssef Melhem Politi," MoM, 11 February 1940.

55“Fonds Youssef Melhem Politi," MoM, 23 October 1932; 11 February 1940; and 26 August 1947.

${ }^{56}$ See Ron Shaham, "Christian and Jewish "Waqf in Palestine during the Late Ottoman Period," Bulletin of the School of Oriental and African Studies 54, no. 3 (1991): 460; and Randi Deguilhem, "Wakf," Encyclopedia of Islam, 2nd ed., ed. P. Bearman et al. Brill Online, 2012, https://referenceworks.brillonline.com/browse/encyclopaedia-of-islam-2.

${ }^{57}$ Request from the majority of the CCS to the Shari'a court in Sidon, "Fonds Youssef Melhem Politi," MoM, April 1925.
} 
to assign the management of all awqāf to the new Jewish commission, Judge Shaykh Rashid Wahba from the Sunni court in Sidon appointed Ibrahim Ma'tuq Nigri to be administrator for a waqf of the Mosaic community (nāzir waqf li-l-țầifa al-Mūsāwiyya) in April 1925. Outraged by the news, the community council of Beirut sent a lawyer to the CCS to initiate a lawsuit against Ibrahim Ma'tuq Nigri. In response, the latter sent a leaflet (nashra) to the CCS in which, according to the minutes, "he insulted the council of Sidon, the religion, the council of Beirut, and the chief rabbi." The event, the minutes relate, "created great confusion." The content of these insults is not known, however the leaflet was reportedly published on the walls of several mosques and synagogues, which is indicative of Ibrahim Ma'tuq's efforts to show the support he received from members of other religious groups in Sidon. A few days later, in May, the Sunni court in Sidon also notified several members of the community council in Sidon that they were being taken to court by Ibrahim Nigri, who was accusing them of stealing the money of the waqf for the poor (waqf fuqarä' al-țâ'ifa al-Isrä'iliyya). In August of the same year, the president of the Beirut community council, Salim Harari, personally came to Sidon to settle the differences between the CCS and Nigri out of court. Yusuf Shmu'el Nigri and Ibrahim Ma'tuq Nigri consequently signed a contract in which they both agreed to resign from their respective positions of administrator of the awqāf, both of which were recognized by the court, once all the awqä properties' renting contracts were stabilized. ${ }^{58}$ Like Braun, Ibrahim Matuq managed to persistently challenge the authority of the CCS and that of Beirut, over a long period of time. By relying on local, interreligious sources of support and arguably former Ottoman waqf practices to reclaim power, he demonstrated a great talent for coping with the new national sectarian order.

\section{Saydawi Jews Against Beirut}

The question that now arises pertains to the influence that Ibrahim Ma'tuq Nigri and Musa Braun really exerted over the local Jewish community. Did they represent or speak on behalf of a more generalized dissent within the Jewish population in Sidon against the new national sectarian order, or were they merely acting to serve their own interests? To start with, reading between the lines of the minutes of meetings "against the grain" reveals muted voices of support for Braun and Nigri. ${ }^{59}$ When the CCS decided to take major actions against Musa Braun in February 1940, for example, the minutes stressed that "people who have allegedly elected him to represent them on a civil as well as religious level have since changed their minds." In other words, Jews in Sidon who openly supported Braun's claims did exist at some point. Similarly, when Judge Wahba was confronted by the CCS about appointing Ibrahim Ma tuq Nigri administrator for the $a w q \bar{a} f$, he justified his decision by arguing that the latter presented a petition signed by thirty people supporting his appointment. Finally, and most decisively, despite the repeated attempts from the Jewish central authority in Beirut to undermine the influence of Braun and Nigri, the two men came out first in the 1934 election for the CCS. Ibrahim Ma'tuq Nigri was elected with 32 votes and Musa Braun with 25 votes, whereas the former president, Youssef Politi, was turned down, having received only 12 votes. Musa Braun (temporarily) became vice-president of the CCS; Ibrahim Ma'tuq became secretary, in charge of the awqäf..$^{60}$

The threat that Braun and Nigri represented to the viability and popularity of the CCS also is perceptible in the sources. In October 1932, the CCS asked the governor of South Lebanon to stop accepting requests from individuals outside the CCS, because the only legitimate authority was the community council of Beirut. In the letter, Ibrahim Ma'tuq Nigri and Musa Braun are both portrayed as real dangers to the community.

[The CCS] asked the governor to take into consideration requests coming from the community council of Beirut only. . . and to stop Ibrahim Nigri from meddling in the affairs of the community... . The council was informed that certain people present themselves as chief

\footnotetext{
58“Fonds Youssef Melhem Politi," MoM, 12 April-29 May 1925; and 4 August 1925 (includes text of agreement).

${ }^{59}$ Ranajit Guha, “The Prose of Counter-Insurgency," in Subaltern Studies II, ed. Ranajit Guha (Delhi: Oxford University Press, 1983), 45-88.

60“Fonds Youssef Melhem Politi," MoM, 12 April-10 May 1925; 11 February 1934; and 11 February 1940.
} 
rabbi or näzir waqf.... The governor should not take this into account because the community (of Sidon) has no chief rabbi and no nāzir awqā $f . .$. The council deals with its ...awqā $f$ and its unique religious reference is the chief rabbi of the Republic of Lebanon: ${ }^{61}$

In spite of the fact that Musa Braun's and Ibrahim Nigri's voices were systematically silenced in the official records of the council because they were "repeatedly acting against the interests of the community," it is important to note that they did not literally constitute a threat to the entire Jewish population of Sidon. ${ }^{62}$ They rather represented a threat to the legitimacy of the CCS as a political structure, as well as that of the council in Beirut. These details indicate that discontent in fact existed in Sidon against Jewish official authorities, enabling Braun and Nigri to lay claims of political and religious legitimacy on behalf of Saydawi Jews, even though they arguably acted in their own personal interests. But given the lack of support from their authorities, how might we explain their success?

The way some of these stories are covered by the Jewish Arabic newspaper al-'Alam al-Isra'ili is of particular interest here. Although the journal based in Beirut mainly represented the interests of the community in the Lebanese capital, Salim Mann also occasionally covered the situation in Sidon. In fact, the journalist had strong connections with the Nigri family and with Yusuf Politi, as Guy Bracha has shown, and readership in Sidon was important. ${ }^{63}$ In several instances, Salim Mann, although he initially backed the official councils, brought a more nuanced perspective to the tensions between Sidon and Beirut. In at least one instance, the title of chief rabbi was used to designate Musa Braun, despite the council's official position, and even though the journal originally had sided with it. ${ }^{64}$

Similarly, with regard to the conflict over the Jewish awqäf, Salim Mann first fiercely supported Beirut and the CCS, but later worked toward finding a compromise. In the early phase, the story was covered from the point of view of the official councils alone. In May 1925, Mann expressed outrage at the appointment of Ibrahim Ma'tuq Nigri as näzir al-awqäf by the Sunni court of Sidon, given that the CCS was in his eyes the only legitimate ruling entity representing the Israelite community and its awqāf: "We thought it was a joke, but our Saydawi friends have confirmed that this is true." ${ }^{65}$ However, in the following issue, a brief note in the form of a disclaimer mentioned a letter the journal had received opposing this point of view. As Salim Mann was traveling to Damascus for a few weeks, the whole case was postponed until his return. In June, an article entitled "A Sahih Hadha?" (Is That True?) covered the whole story, this time from a completely new angle, expressing the editor's mounting doubts. ${ }^{66}$ Finally, Ibrahim Ma'tuq Nigri was even invited to respond "in his capacity as legal wāli for all awqā $f$ of the Israelite community." Nigri argued that the community had never acknowledged the authority of Beirut: "The community rules itself by itself." 67

Chief editor Salim Mann's change of attitude indicates that Nigri was not, it seems, the only one to support this point of view. A few years later, in September 1932, the Nigri case was again discussed by al-'Alam al-Isra'ili in the context of tensions between two opposing camps. One camp was led by Youssef Politi, president and representative of the CCS, and the other by Nigri and his followers. The

\footnotetext{
${ }^{61}$ Ibid., 27 and 28 December 1931; 3, 4, and 10 January, 28 February, 16 May, 12 June, and 23 October 1932. Quotation from 23 October 1932.

${ }^{62}$ Ibid., 12 June 1932.

${ }^{63}$ Bracha, “Al-'Alam al-Isra'ili," 201.

${ }^{64}$ Al-'Alam al-Isra'ili, 15 April 1938. I thank Guy Bracha for sharing this.

65“Awqāf al-Yahūd fỉ Șayda”, Al-'Alam al-Isra'ili, 7 May 1925, https://www.nli.org.il/en/newspapers/alalam/1925/05/07/01/? \&e=------en-20--1--img-txIN\%7ctxTI------------1.

66“'A Sahịh Hādhā?”, Al-'Alam al-Isra'ili, 11 June 1925, https://www.nli.org.il/en/newspapers/alalam/1925/06/11/01/? \&e=-------en-20--1--img-txIN\%7ctxTI-------------1.

67“'Awqāf al-Yahūd fï Șayda”, Al-'Alam al-Isra'ili, 18 June 1925, https://www.nli.org.il/en/newspapers/alalam/1925/06/18/01/? \&e=------en-20--1--img-txIN\%7ctxTI------------1. The titles of the individuals in charge of the awqäf for the Jewish community varied according to time, place, and function (nāzir, wālī, wakīl, or mutawallī, among others). Interestingly, Ibrahim Ma'tuq Nigri included in the signature, in Arabic, an Islamic greeting used exclusively by Muslims to fellow Muslims, "al-salām 'alā man ittaba'a al-hudä" (Peace be upon those who follow true guidance). His choice of language remains difficult to interpret, but several hypotheses can be suggested here. First, Nigri uses a Muslim greeting to speak with authority. Alternatively, he wants to display familiarity with common Muslim salutations to stress the mixed environment of his social life. Also, Nigri might have needed to justify the appointment of a Christian lawyer for supervision of the Jewish awqäf. I thank Ahmad Dallal and Guy Bracha for their input.
} 
president, Politi, stood accused of corruption and Nigri of "looting" the waqf funds. Salim Mann tried not to take sides in the dispute: "Al-'Alam al-Isra'ili implores its brothers to call upon friendship, unity and sacrifice ... in the service of the community." ${ }^{68}$ But once the breach was open, new accusations poured in. At one point, the tension was so high that the community council in Beirut submitted a petition to the president of Lebanon, Charles Debbas, for intervention. The affair started with al-'Alam al-Isra'ili publishing an anonymous letter from "a concerned Israelite" who expressed doubts about the transparency of the CCS. Despite the journal's continued efforts to reaffirm the legitimacy of the CCS, an article entitled "Where does the Waqf. . . Money Go in Sidon?" (Ayna Tadhhab Amwal ... al-Awqaf fi Sayda) was published, followed by two others anonymously signed by "a truly neutral Israelite" (Isrä'ìli mutahàyid) discussing the same topic. ${ }^{69}$ Although attempting to stay "truly neutral," the articles demonstrated the general dissatisfaction with the Israelite Community Council in Beirut, and the absence of acknowledgement for its authority over Sidon:

I am an Israelite Saydawi (Șaydāwì Isrā'ìlī), completely neutral and I do not interfere at all with the two parties. Youssef Politi's party has asked the chief rabbi in Beirut and the community council to come to Sidon for the elections. But I do not understand the relation between the community council in Beirut and the affairs of the Israelite community in Sidon. What right does it have to interfere in our ... affairs? We were not the ones who elected it so it has not even the smallest authority over our community. If Beirut wants to interfere in the affairs of Sidon, then the Jewish population of Sidon should participate in the elections of the community council in Beirut the same way the community in Beirut does [in Sidon]. ${ }^{70}$

Finally, other strategies attempted to bypass Beirut's authority. Evidence reveals that influential Jews from Sidon negotiated directly with the Lebanese administration for their own political empowerment in the region, rather than consulting with the Jewish council in Beirut. In particular, Salim Mann wrote a sarcastic note in the column for local events in al-'Alam al-Isra'ili about the appointment of Jews from Sidon to the administrative council for the governorate of South Lebanon in 1925. Two people were appointed to the position, Musa Murad Lawi and Musa Braun. ${ }^{71}$ With bitter irony, Salim Mann expressed hope that the government would act in a similar manner to the governorate of Beirut by appointing more Jews to its administrative council. After all, Mann argued, today the greatest Jewish merchants and bankers are in Beirut, no longer in Sidon. Behind the irony, however, Mann could barely hide the general outrage triggered by the news within the community in Beirut of Jews from Sidon going over their heads to gain political power without them. ${ }^{72}$

In Sidon, a tense political battle was playing out between Jewish official authorities trying to impose their rule from Beirut and some individuals, Musa Braun and Ibrahim Ma'tuq Nigri most saliently, trying to impose theirs in Sidon. In this battle there was no obvious winner, and the rest of Sidon's Jewish community most probably positioned itself somewhere in between the two camps. Nevertheless, two dimensions-at least-need to be considered here to understand the complex processes of constructing differences and similarities within the Jewish community in Lebanon. One is sect-specific: the Jewish community councils in Beirut and Sidon envisioned their communities as primarily bound by their sect (al-tâa ifa). Its members used the reconfiguration of political structures provided by national sectarianism-or sectarianism from above-to claim from below legitimate authority over all Jewish communities in the country. The other is space-specific; the way some Jews in Sidon envisioned their authority depended primarily on localized dynamics of power and influence, partly inherited from Ottoman administrative practices and

\footnotetext{
68“Al-Mushkila al-Mu'aqqada fì Șayda”, Al-'Alam al-Isra'ili, 12 September 1932, https://www.nli.org.il/en/newspapers/alalam/ 1932/09/12/01/?\&e=------en-20--1--img-txIN\%7ctxTI-----------1.

${ }^{69}$ Al-'Alam al-Isra'ili, October 1932. The exact date of the anonymous letter is unknown.

70 "Kafākum Ayyuhā al-Nās Taḍlīlan”, Al-'Alam al-Isra'ili, 24 October 1932, https://www.nli.org.il/en/newspapers/alalam/ 1932/10/24/01/?\&e=-------en-20--1--img-txIN\%7ctxTI-------------1.

${ }^{71}$ Voices of objection rose about Braun's and Lawi's nominations. Eventually, the person appointed to be the Jewish member of the administrative council was neither Lawi nor Braun, but Yusuf Effendi Nigri.

72 "Nahnu fì-1 Majlis. Bayrūt wa Șayda”, Al-'Alam al-Isra'ili, 30 July 1925, https://www.nli.org.il/en/newspapers/alalam/1925/ 07/30/01/?\&e=-------en-20--1--img-txIN\%7ctxTI-------------1.
} 
partly from their social or interreligious experiences rooted locally. These categories are not mutually exclusive; the fact that Nigri and Braun used space-related dynamics to reclaim power in their own names does not mean that they did not also make use of other forms of sectarianism. And, inversely, space-specific power struggles were arguably at stake in Beirut, too. However, as a result of these complex processes, new forms of sectarianism produced by the national frame and implemented by Jewish community councils to subject Saydawi Jews to Beirut were met with persistent resistance, because other expressions of solidarity involving Sidon's localized identity were also at stake.

Acknowledgments. I would like to warmly thank the anonymous peer reviewers, as well as IJMES editor Joel Gordon, who offered incisive yet encouraging feedback. Their comments helped me strengthen my argument and improve my analysis. The colleagues who attended the Jews in Muslim Majority Countries conference at the Jewish Museum in Berlin in 2017 offered invaluable and thoughtful comments on an earlier version of this paper. Also, for their feedback or precious time spent reading the first draft, I wish to express my heartful thanks to Frédéric Abécassis, Seth Ansizka, Philippe Bourmaud, Guy Bracha, Ahmad Dallal, Efrat Gilad, Iyas Hassan, Anaïs Massot, Akram Zaatari, and Zvi Zohar. Finally, I am enormously grateful to Yolla Polity for her time, patience, and trust while sharing her family history and archives with me.

Cite this article: Schlaepfer A (2021). Sidon against Beirut: Space, Control, and the Limits of Sectarianism within the Jewish Community of Modern Lebanon. International Journal of Middle East Studies 53, 424-438. https://doi.org/10.1017/ S0020743821000180 